\title{
Inter-caste Marriage and the Impact on the Intra-cultural Communication Pattern of Balinese Hindu in Indonesia: An Ethnography Study
}

\author{
Ni Putu Limarandani ${ }^{1}$, Ahmad Sihabudin ${ }^{1,2}$, \& Mirza Ronda ${ }^{2}$ \\ ${ }^{1}$ Post Graduate School of Communication Science, Sahid University, Jakarta, Indonesia \\ ${ }^{2}$ Communication Department, Sultan Ageng Tirtayasa University, Indonesia \\ Correspondence: Ni Putu Limanrandani. Tel: 62-878-8382-1081. E-mail: limarandaninp@gmail.com
}

Received: January 15, 2019 Accepted: January 29, $2019 \quad$ Online Published: February 28, 2019

doi:10.5539/ass.v15n3p40

URL: https://doi.org/10.5539/ass.v15n3p40

\begin{abstract}
Intra-cultural communication of the Balinese community, acted as a representation of cultural and social identity. This intra-cultural relationship has consciously built relations of power in the life of the Balinese Hindu community including in very personal matters such as marriage. There are two kinds of marriages for Balinese Hindu, memadik (wooing) and ngerorod (eloping). The second married arose when women from high caste married with a man from a lower caste. In the Dutch colonial era, this kind of marriage was outlawed, since this time categorized as unexpected marriage. One of the consequences of eloping married, known as nyerod in Bali is a decline in the caste of the bride as same as the groom. Accordingly, the couple should change their ways of communication when they interact with the bride family. The aims of this paper is to describe the intra-cultural communications among the nyerod couple with their family and the indigenous environmental in Balinese Hinduism. The ethnography approach was taken to describing and analyzing the primary data from interview and observation. The result shows that the intracultural communication pattern among nyerod women and their parent, sibling and extended family, represent by their impression management. The foundation of interactions are the form of their identity which develops in four layers and bound by customary law.
\end{abstract}

Keywords: intracultural communication, inter-caste marriage, impression management

\section{Introduction}

The homogeneity of Balinese people, producing a pattern of typical and unique communication that exists only on the life of the Hindu community in Bali. The interaction pattern is reflected in the variety of religious rituals and customs inherent Balinese are very powerful in the lives of the people. A variety of activities religion and ritual interaction in the custom into the identity of the citizens and people of Bali.

The communication pattern among Balinese Hindu communities can be seen from the name, the religion and cultural symbol in the private and the public sphere. Naming in the community is important because it identifies one's place in the caste hierarchy. Furthermore, Balinese name usually consists of three elements, namely the birth-order name, the status title, and the personal name (see, June, 2016) as the table in Segara (2015).

The use of the symbols of the name also as a clue of how they should communicate with each other based on their caste. In practice, the three high castes (Brahman, Kshatriya, and Veisya) or triwangsa, usually are not used their order name, they prefer to use the title status to highlight their decency. The greeters and interlocutors required to aware of their position in the family and public sphere when interacting. Essentially, each should choose the right greeting word based on manners and customs norms (Sujiwa, 2018). The greetings according to position distinguish age and social strata, therefore the greetings used will appear to vary.

The complexity of naming and greeting in the caste (wangsa) system in Balinese Hindu, has an impact on the interaction in the marriage of women who married a man from a lower caste. The triwangsa women who choose to be married with the man from a lower caste would face several concerns includes a greeting in the family and indigenous environmental. The process called as nyerod, a marriage that is done not through the proposal, nevertheless instead fleeing the bride and a groom hide it. This marriage is not expected by the nuclear and big family of the bride since the bride should decline her caste as same as the groom. Accordingly, the couple should 
change their way of communication when they interact with the bride family.

In practice, the changes in language use is not a tranquil thing, since is painful for both perpetrators and their parents. This difference in greeting applies also to the children of the nyerod couple, they must behave according to the rule of inter-caste interaction between the low and the high. The aims of this paper is to describe the intra-cultural communications among the nyerod couple with their family and the indigenous environmental in Balinese Hindu.

\section{Research Method}

Following the qualitative and research design of Creswell (2013), I designate an ethnography approach to describe and interpret the communication patterns among nyerod couple with her extended family and indigenous environment. As unexpected married, limited couples of nyerod are willing to discuss their married, thus I only gather the primary data from 3 couples. Interviews and observations were operated to explore the data from the informants. Interviews were also conducted with politician and academics.

\section{Theoretical Framework}

\subsection{Marriage in Balinese Hindu}

A marriage in the Balinese Hindu can be seen in term of circulation of jural females around fixed patrilines that, in turn, constituted by heredity caste (Bagus, 2008). The written provisions containing various regulations relating to marriage are found in the Manawa Dharmasastra Adyaya IX book which consisting of 336 articles (Griffith, 2005). The book is used as a reference and guide to the marriage in the community.

The Manawa Dharmasastra article II.67 stated that Wiwaha Samskara is a sacred ceremony which is a mandatory humanitarian event for Balinese Hindu. Consequently, in their daily life, the society clings to the dharma, especially household life, as explained in Manawa Dharmasastra IX. 101 and 102 as cited by Pudja (2003):

\section{"IX.101 : Anyonyasyawayabhicaro, bhawedamaranantikah, Esa dharmah samasena jneyah stripumsayoh parah}

Meaning: A faithful relationship must last until death, in shorts, this must be regarded as the highest law as husband and wife.

IX.102 : Tatha nityam yateyatam stripumsau tu kritakriyau Yatha nabhicaretam tau wiyuktawitaretaram"

Meaning: $\quad$ The men and women should be bound in marital bonds, try not to fade so that they are not divorced and should not violate loyalty between one another.

(Pudja, 2003)

The shloka illustrates that marriage is the foundation of family development and which lasts once in human life. The Married couples must maintain their chastity, live in harmony and peace, happiness, strive for the establishment of personality and inner and outer calm in an effort to give birth to a good child (suputra). According to this verse, whatever happens in a household that can divide this marriage must be tried to overcome, therefore divorce will never occur because it is a violation of obligations or denying the bond of the holy marriage.

There are two traditions of marriage for Balinese (Segara, 2015), namely: (1) marriages that are carried out by way of memadik (propose), which includes (a) ordinary marriage, (b) nyetana and (c) padagelahang, and (2) is ngerorod or eloping. An ordinary marriage is a process that took place at the home of the groom because her husband's status as a kapurusa will be in charge of full and bride as pradana. Furthermore, the women will release the legal relationship with her family and becoming a part of the husband family. The second form of proposal conjugal is nyentana, an event that took place in the bride house, since the women's status as kapurusa (in charge of the life of the husband) and a man as pradana (the party that incurred), subsequently a man letting go of a relationship with the origin family. This usually occurs due to conjugal in one family had no male descendants and children follows the lineage of his mother. The last type of mating is padagelahang, a connubial which put men and women as kapurusa. The condition is representing each of which has two responsibilities and obligations in their own family. The mating usually occurs in families that have a child and not pleased to follow custom marriage or nyentana.

The second kind of marriage is ngerorod which in the past, it outlawed. The norms stated in the Manawa Dharmasastra shloka III.13., which probed the man and women to indicate their couple from the equal caste 
(warna) (Pudja, 2005):

"Cudrasya bharya cudraiwasam caswa ca wicah smrte

Te ca swa caiwa rajnacca tacca swa carpajanma-nah"

Meaning:

As stated that only sudra women could be a wife of sudra men, and Vaisya women to be a wife of vaisya man, kshatrya to be a wives of kshatrya, and the three colors include brahman women to be a brahman wife.

(Pudja, 2005)

The shloka interpreted to regulate women only in choosing their partners. This reflected in the next article, which regulates inter-caste marriage. The Manawa Dharmasastra X.5, state that there are two forms of inter-caste marriage Anuloma and Pratiloma. Anuloma labeled to the marriage, which a women caste is one caste below her husband and patiloma is the marriage between women from the caste, which two or three castes lower than her husband is. The children from patiloma marriage called abastha if her mother two castes lower, and nisada or parasawa if her mother is three castes lower. Hence, the system provides an opportunity in Hindu law to regulate polygamy, which allows triwangsa men to have more than one wife with a maximum provision of four. In practice, this verse often obscured so that there is a tendency for unlimited polygamy and such things are contrary to religious law. Now a day, there is the regulation, which rejected the anuloma and patiloma.

The misinterpretation of marriage regulations for Balinese elite castes (triwangsa), triggers of the second type of marriage, ngerorod or nyerod which triwangsa women, choose to be married to the man from a lower caste. According to Dutch colonial law and some high-caste traditions, inappropriate marriages outside caste boundaries were punishable by exile (selong), often to another island in the archipelago and usually for a fixed period of time (M.Ida Bagus, 2008). Recently, nyerod categorized as unexpected married, and the consequences are varied in every family.

\subsection{Intracultural Communication in Balinese Hindu}

Communication among member in the same culture sometimes more complex than imagined, especially in the culture that emphasizes the use of language when interacting. The homogeneousness of Balinese creates a specific communication pattern which not found in other Indonesian sub-culture. The intracultural communication can consider as shared interpersonal communication between members of the same cultures (Lewis \& Slade, 1994), share common nonverbal and verbal behavior patterns, common rules and common goals (Collier et al., 1986) and how to make conversation meaningful among member (Toyosaki, 2011).

Develop by Edward Hall in 1976 (Shuter, 1990), intracultural communication was not applied as wide as intercultural communication. Futhermore, Shuter (1990) describe what the research of intracultural communication could help us to increase our understanding of society and inextricable linkage between communication pattern and sociocultural forces. According to Hall (1966) as cited by Shuter (1990) pattern are the common, unstated experiences which members of a given culture share, communicate without knowing, and which form the backdrop against which all other events are judged.

Names, religious ritual and cultural symbols in private and public spheres are the pattern that shared amongst community members of Balinese. Naming, as state previously is an important symbol of the caste system, and the inclusion of any name may not be arbitrary as determined by the awig-awig (traditional edict). The other nonverbal symbols of intracultural communication in the private sphere is a form of utterances, in a certain situation, they must practice sor singgih basa (levels of Balinese language). There are four levels of language that use by elite castes namely, halus singgih, halus sor, halus madia and mider (level of polite words/language). Each level should be implemented appropriately to make the message meant for themselves.

In practice, verbal and nonverbal communication represent by prioritizing the elite caste in expressing their opinion in Bale Banjar and wantilan (worship place) as a symbol of giving honor and traditional ethics. When the quarterly group expresses their opinions, then all traditional leaders and the people present will listen carefully, not noisy or not cutting the opinions that are being conveyed. If there are those who disagree, traditional leaders and the community will convey with an apology in advance while including both hands in the chest (anjali attitude), and articulated an opinion. In addition to getting priority and prioritizing the presentation of opinions in the form of meetings, the triwangsa will be positioned primarily in enjoying the dish served, then followed by traditional leaders and in the last line is a sudra group (the lowest caste in the social system).

The pattern of non-verbal communication in the public domain exemplified in the symbols of religious rituals, 
such as; rituals of the death (ngaben), cut teeth, marriage, and others. Symbols of non-verbal communication of religious ceremonies in the form of marriage characterized by the form their wedding attire, which has distinctive features and forms of Balinese culture. A wedding dress epitomized an awareness of cultural identity and representation of adherence to customary and religious rules.

In the context of marriage, there is a level of wedding dresses known as "payas". There is a Payas Agung, the form of clothing for the highest or highest level in the social strata during the Badung empire. Moreover, the payas is only reserved for the royal family during the marriage procession of Royal or triwangsa families. In addition to Payas Agung there are also middle payas which indicate intermediate levels, intended for marriage processions and lower social levels. Conversely, for the lowest strata, there is a Payas Nista, which looks very simple, commonly reserved for the general public of Bali such as farmers or fishermen.

\subsection{Identity and Intracultural Communication}

An identity is a key element of subjective reality and connected dialectically with the community. The identity formed by social processes, and its formation determined by social structure. An identity present in all type of relationship, intracultural, intercultural and interpersonal (Imahory \& Cupach, 1993). The identity is in a wide range of cultures and humans are different in describing themselves. Cultural identity linked individuals and society, and communication is the bond that allows a relationship to occur (Littlejohn, 2012).

In addition to the definition of identity, Hecth (2010) describe identity exceeds that of what the self-dimensions and dimensions are depicted. The two dimensions interact in a series of four levels or layers, namely the personal layer, which is the feeling of being in a social situation. The level of both the enactment layer or the knowledge of others about yourself, the third level of relational or who you are in relation to other individuals and the last is communal which is tied to a larger group or culture. In this paper, the identity theory works to analyze the process inside the nyerod women, when they are intermingled with their family and indigenous community.

\subsection{Intracultural Communication and Inter-Caste Marriage}

Inter-caste marriage such as nyerod is not a choice marriage since being considered to cause disgrace to the family, especially the female family is also detrimental to women's position. A woman from elite castes, who indicate nyerod should alter her identity through the patiwangi rituals. The sacramental is to decline the women caste to be the same as her husband, such as form triwangsa to jaba/sudra. The change in identity is demanding, in the end not only has an impact on demeanor in the extended family, but within the indigenous community also Consequently, they are required to bear their new identities on every occasion. In fact, not all actors can easily accept this change of dealing, thus they must be able to manage their deeds while in the adat environment.

Kade, Sri, and Era, are the women who willing to share their experiences of nyerod. Kade was the daughter of Brahman, and she decides to marry a sudra man, which knows from social media. Afterward, she was rejected by her extended family and the neighborhood where his parents came from. Moreover, all the nobility is removed and she compulsory to changes her habits of communication. Later, she required to use the sor singgih, when she interacted with her parents, she should call her mother "ratu" front of his vocation. In association in the community, Kade requisite a positioned as a sudra, which should be called by name without an honorable title.

Nyerod experiences vary for each pair, as experienced by Era and Sri. One week after his marriage, Era's parents agreed to her decision to marry a Sudra man. Even though her extended family did not approve, Era remained firm with her decision. While Sri, although choosing the same partner from the khsatriya, however since her husband's family experienced the caste abolition (nyineb wangsa), hence he could not use his peerage. Therefore, her indigenous people asked for ngerorod, and she must customarily follow all provisions related to inter-caste marriage, which she does.

The communication pattern among nyerod couple and her nuclear and extended family are depended to their sub-culture circumstantial. Kade, who was brahmana family and lives in the suburbs, certainly has a different understanding with Sri and Era who live in cities. Although all three were highly educated, their parents' views differed as well as the attitudes of their extended family. Kade's family, the orthodox, made it hard for her to admit the costs of the unexpected marriage. She must have uneven with his parents in the first years of the marriage. The behavior of a large family, making it like a stranger, moreover she set notwithstanding, and always left behind at every family religious ceremony. When gathered with her extended family, she always received spicy words, and awkwardly, she could not communicate as usual with his mother, father, and brother. An appropriate Balinese naming should be use when interacting with them. The other two informants also used sor singgih when dealing with their families. However, they did it voluntarily, and as a sign of respect for their extended family. 
The research finding showed that the models of interactions concerning the nyerod couples within the nuclear family are strongly bounding by customary rules. The caste system makes community groups fragmented and when inter-contacts, certain binding rules needed.

\section{Discussion}

The existence of Balinese Hinduism cannot separated from the culture itself. The Balinese Hinduism befits as a system of values and norms that implemented in an actions and social systems. The system manifested in the form of great and enchanting cultural materials. All symbols in the community describe their cultural identity. The caste/wangsa in Balinese Hindu represents an identity that distinguishes the way the members of the community interact.

Agreeing with Hecht, identity exceeds what the self-dimension and the research finding shows that it could seen in interacted pattern with their family. The nyerod women presented verbal and nonverbal behavior as expected by their environment; moreover, it brings to the second layer of identity. The second layer, enactment or other people's knowledge about yourself, hence at this stage, the individual seen and treated according to the views of others towards her. The couples, for example, requires performing various rituals and usages various symbols in accordance with customary provisions. The woman who decided nyerod, generally label as "discarded daughter", and categorize them as jaba. Consequently, they must use new symbols as the jaba (the lowest caste) when communicating with the elite caste. This layer makes someone's identity in the third level of relational as relations to other individuals.

The communal, as the last layer of nyerod women identity represent by their linkages with the customary law, which tied them to a larger group or culture. This layer is a form of socialization of the identity carried by each individual, in this case, a new identity after releasing his nobility. The women from elite caste, in nyerod context dominated by social structures in Balinese Hindu culture. Following Erving Goffman's view, identity in groups can create stigma, namely feelings of inferiority or feelings of shame that someone might feel like a failure to meet other people's standards. Additionally, Goffman illustrates as the tension between "I" and "Me", besides it influenced by social barriers. All the actors themselves are involved in impression management because they all prioritize creating a respectable impression on others. This concept raises the social meaning of self or situational social self-concept since it constantly demanded by different social roles in the short term.

The intra-cultural communication pattern of nyerod couples with their family could be figure out in the diagram in Figure 1:

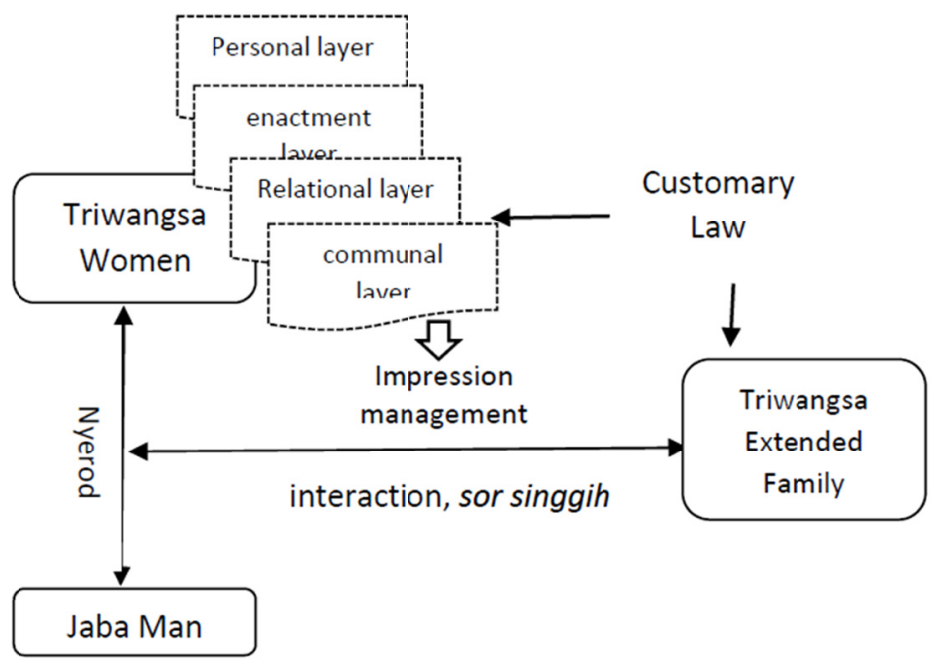

Figure 1. The model of intracommunication pattern in the family of nyerod couple

The model explained how intra-cultural communication in the context of marriage carried out by triwangsa women after her nyerod marriage. The cultural identities after the marriage, have an important role in building impression management while interacting with her extended families. Both parties are bound by the applicable customary law.

\section{Conclusion, Limitation, and Future Research}

The intra-cultural relationship has consciously built relations of power in the life of the Balinese Hindu, 
including in personal matters such as marriage. The customary law is not just a part of symbolism but has converted as a part of their cultural identity, something rooted in the lives of every Balinese citizen, as well as being a binder of behavior and acting in society. While on the other side it can be a problematic realm in the personal life and culture of the Balinese Hindu. The limitation of current study is the deepest of information around their marriage, as nyerod still became a disgrace to the family. Therefore the future research should try to find out about the issue among modern Balinese Hindu community, which could provide the reference for appraising the traditional law of inter-caste marriage.

\section{References}

(2003). Manawa Dharmasastra. Jakarta: Pustaka Mitra Jaya.

Bagus, I. G. N. (1990). Kebudayaan Bali. Denpasar: Djambat.

Bagus, M. I. (2008). Mixed Marriages in Jembrana, Bali: Mediation and Fragmentation of Citizenship and Identity in the Post-bomb(s) Bali World. The Asia Pacific Journal of Anthropology, 9(4), 346-362. https://doi.org/10.1080/14442210802493678

Cahyaningtyas, J. (2016). Inter-caste marriage in Bali: A gendered analysis of caste and its impact on Balinese women. Asian Journal of Women's Studies, 22(3), 193-207. https://doi.org/10.1080/12259276.2016.1205374

Collier, M. J., Ribeau, S. A., \& Hecht, M. A. (1986). Intracultural Rules and Outcomes within Three Domestic Cultures. International Journal of Intercultural Relations, 10, 439-457. Pergamon Journal Ltd. https://doi.org/10.1016/0147-1767(86)90044-1

Creswell, W. (2013). Qualitative Inquiry Research Design: Choosing among five approaches. Sage, USA.

Griffith, R. T. H. (2005). Yajurveda Samhita. Penterjemah: Dewanto, S.S: Surabaya: Penerbit Paramita.

Liliweri, A. (2011). Dasar-dasar komunikasi Antar Budaya. Yogyakarta: Pustaka Pelajar.

Littlejohn, S. W. (2010). Theories of Human Communication. Jakarta: Salemba Humanika.

Littlejohn, S. W., \& Foss, K. A. (2009a). Theories of Human Communication (9th ed.). Jakarta: Salemba Humanika.

Littlejohn, S. W., \& Fross, K. A. (2009b) Encyclopedia of communication Theory. Thousand Oaks. California: Sage Publication. https://doi.org/10.4135/9781412959384

Pudja, G. (1975). Hukum Kewarisan Hindu Yang Diresepsir Ke Dalam Hukum Adat Bali dan Lombok. Jakarta: CV. Junasco.

Pudja, G. (2005). Bhagawad Gita. Surabaya: Paramita.

Segara, I. N.Y. (2015). Perkawinan Nyerod. Jakarta: PT. Saadah Pustaka.

Shuter, R. (1990). The centrality of culture. Southern Communication Journal, 55(3), 237-249. https://doi.org/10.1080/10417949009372792

Suwija, I. N. Y. (2018). Sistem Sapaan Bahasa Bali Menurut Hubungan Kekerabatan, Sosiohumaniora. Jurnal Ilmu-ilmu Sosial dan Humaniora, 20(2), 115-121.

Toyosaki, S. (2011) Critical Complete-Member Ethnography: Theorizing Dialectics of Consensus and Conflict in Intracultural Communication. Journal of International and Intercultural Communication, 4(1), 62-80, https://doi.org/10.1080/17513057.2010.533786

\section{Copyrights}

Copyright for this article is retained by the author(s), with first publication rights granted to the journal.

This is an open-access article distributed under the terms and conditions of the Creative Commons Attribution license (http://creativecommons.org/licenses/by/4.0/). 